\title{
Are State Legislatures Responding To Public Opinion When Allocating Funds For Tobacco Control Programs?
}

\author{
Angela Snyder, M.P.H. ${ }^{1,2}$ \\ Tracy Falba, Ph.D. ${ }^{1,2}$ \\ Susan Busch, Ph.D. 1,2 \\ Jody Sindelar, Ph.D. ${ }^{1,2,3}$
}

June 10, 2003

From ${ }^{1}$ the Department of Epidemiology and Public Health, Yale University School of Medicine, New Haven, CT; ${ }^{2}$ the Center for Nicotine and Tobacco Use Research at Yale; ${ }^{3}$ NBER and Institution of Social Policy Studies

Corresponding Author: Angela Snyder, School of Public Health, Yale University School of Medicine, P.O. Box 208034, New Haven, CT 06520-8034

Phone: (203) 752-0716, FAX: (203) 785-6287, email: angela.snyder@yale.edu

Acknowledgements: This research was supported by a grant from the Robert Wood Johnson Foundation (\#039787), as part of the Transdisciplinary Tobacco Use Research Center at Yale and an AHRQ Training Grant supporting Yale Ph.D. students.

To be submitted to: Health Policy Promotion and Practice (accepted for publication 1/23/04) 
Title: Are State Legislatures Responding To Public Opinion When Allocating Funds For Tobacco Control Programs?

\begin{abstract}
:
This study explores the factors associated with state-level allocations to tobacco-control programs. The primary research question is whether public sentiment regarding tobacco control was a significant factor in the states' 2001 budget decisions. In addition to public opinion, several additional political and economic measures were considered. Significant associations were found between our outcome, state-level tobacco control funding per capita, and key variables of interest including public opinion, amount of tobacco settlement received, the party affiliation of the governor, the state's smoking rate, excise tax revenue received, and whether or not the state was a major producer of tobacco. Little or no association was found between funding and other political and economic measures including the party control of each legislative house, the state's political ideology, mean income per capita, or the state's unemployment rate. The findings from this study support our hypothesis that states with citizens who favor more restrictive indoor air policies allocate more to tobacco control. Furthermore, states with democratic governors spend more on tobacco control compared to their republican counterparts. Effective public education to change public opinion and the cultural norms surrounding smoking may impact on political decisions and in turn increase funding for crucial public health programs.
\end{abstract}

Keywords: Master Settlement Agreement, public opinion, tobacco control, smoking 


\section{Introduction}

A variety of factors influence state-level funding decisions for tobacco control programs. Societal norms regarding smoking and tobacco control, political factors, fiscal health, and need may all be important determinants of a state's funding decisions. The unprecedented amount and unrestricted nature of the revenue each state received from the Master Settlement Agreement creates an opportunity to study these factors, particularly since one of the goals of the agreement is to support "tobacco related public health measures". 1 By 2000, most state legislatures were given the task of allocating the settlement dollars, totaling \$246 billion in new monies over the first 25 years. While the Centers for Disease Control and Prevention (CDC) estimates that to fully implement a comprehensive tobacco control program states should be spending between $\$ 5$ and $\$ 20$ per capita, to date most states have not met these recommendations. ${ }^{2}$

This research examines the amount of tobacco settlement revenue and other state monies that were allocated to tobacco control by states in 2001. The primary research question is whether the lawmakers' decisions reflected public sentiment regarding tobacco control or whether other factors took precedent. We hypothesize that states with citizens who favor stricter indoor air laws and thus regulation of tobacco will allocate more to tobacco control. The focus on public opinion's influence on tobacco funding is a contribution to this area of research, as it has not been examined in extant literature in this context.

We construct a state level public opinion index concerning attitudes about indoor air laws using the 1998-1999 Current Population Survey Tobacco Use Supplement (1998-99 CPS-TUS). This index is used to approximate public opinion about smoking prior to the 2001 appropriations decisions and prior to the allocation of the settlement revenue. 


\section{Background}

While previous research has examined the relationship between public health needs and tobacco-control funding at the state level, other social, political, and economic factors considered relevant to state-level funding decisions may also play a role.

\section{Tobacco Control Funding}

In addition to the established funding sources available to states from both general and tobacco excise tax revenue, by 2000 all 50 states received an additional source of revenue arising from the settlement agreements with the tobacco industry. The November 1998 Master Settlement Agreement with 46 states is estimated to total 206 billion over the first 25 years and specifically states that one goal of the agreement is to support "tobacco related public health measures". 3 An additional 40 billion in settlement dollars was previously reached between the tobacco industry and four states--Florida, Minnesota, Mississippi, and Texas, for a total of 246 billion dollars distributed among 50 states. With the agreements placing no restrictions on how the states spend the funds, the allocation of this windfall became an important legislative task beginning in 2000 .

Recent research into state expenditures for tobacco-control programs by Gross and his colleagues found that state health needs measured by the tobacco-related health burden appear to have little effect on state-level tobacco program funding. Their research found that the proportion of settlement funds allocated to tobacco-control programs was the primary determinant of total funding. ${ }^{4}$

\section{Smoking Rates}

The study by Gross et al. is the only study known to date that explored factors associated with tobacco control spending at the state level. While the authors found no relationship between a state's health needs and spending, they did find a significant association between a 
state's smoking rate and expenditures for tobacco-control programs. Specifically, states with higher smoking rates had lower expenditures for tobacco control, even when controlling for the tobacco-producing states. This result seems counter-intuitive if states were making program allocation decisions based on need, but if the smoking rate is actually a crude measure of public sentiment then it might be that smokers are less supportive of tobacco control programs and are themselves an influential political interest group.

\section{Public Opinion}

Previous studies have shown that high levels of public support, even among smokers, exist for smoke-free policies in many settings. ${ }^{5}$ However, research has also shown that in certain settings, like restaurants, the proportion of people who think smoking should be banned differed among states--ranging from $44.3 \%$ in North Carolina to $63.6 \%$ in Montana and also differed widely between smokers and nonsmokers (median: $25.9 \%$ for smokers versus $66.2 \%$ for nonsmokers). ${ }^{6}$ As much as these public attitudes are proxies for public concern for tobacco control and prevention, they may have an impact on the political process and in turn the funding of tobacco control programs. Greater public support for smoke-free indoor air policies could also represent stronger social and cultural norms against tobacco use compared with other parts of the country. These norms may also lead public officials to accelerate funding for more comprehensive tobacco-control programs.

There is anecdotal evidence to suggest that public support and effectiveness of tobacco programs does little to ensure future funding. In 1999, a community-based intervention in Florida purportedly dropped the teen smoking prevalence rate from $23.3 \%$ to $20.9 \%$ in a year. Prior to the legislative session, public opinion poll results were released indicating that $81 \%$ of the voters thought that the Tobacco Pilot Program should be funded at least at the $\$ 61$ million dollar level proposed by the governor with $57 \%$ preferring no cuts. Even with this information 
Florida’s legislature cut the program’s funding from $\$ 70.5$ million to $\$ 38.7$ million, and the Governor dismantled the program's administrative structure. ${ }^{7}$

\section{Political Factors}

Many political factors might influence the funding of tobacco control programs at the state level. For instance, the partisanship of the legislature, the political affiliation of the governor, the political influence of the tobacco industry, and a state's political ideology may all play a role. In their study of state policies regarding youth access to tobacco products, Luke, Stamatakis, and Brownson (2000) found that state political characteristics were more strongly related to youth tobacco control policies than economic characteristics. ${ }^{\mathbf{8}}$ The authors created a state policy score with higher values signifying states with more restrictive youth access policies; the mean score was higher in states with democratic party leadership although results were only significant for the party control of the lower house. Political ideology may separately influence funding or tobacco control decisions. Ideology, defined on a scale of liberal to conservative, is not the same as partisanship. In fact, Wright, Erikson, and McIver find that state partisanship and ideology are virtually uncorrelated. ${ }^{9}$

\section{Master Settlement Agreement}

Other economic factors may also play a role in the funding of tobacco control programs. The primary fiscal concern in funding any state-level program is how much (new) money is available for appropriation. In the case of a comprehensive tobacco control program, a considerable amount of new money was potentially available from the settlement revenue in 2001.

\section{Other Variables}

In addition to the settlement revenue, funds are also available at the state-level from cigarette excise tax and general state revenues. Several states use the proceeds from excise taxes 
to fund their tobacco control programs, so this additional income stream is also an important consideration.

Of course, there are always competing needs at the state level in the budgeting process. Since state lawmakers are required to balance the state's budget at the end of each fiscal year the funding of tobacco control programs competes with funding for health services, long-term care, research, education, and other children and youth programs, to name a few. Even in states like California and Massachusetts where successful ballot initiatives increased the cigarette excise tax, there were battles among all parties including the legislature, administrators, and the health community to divert tax revenues earmarked for tobacco prevention programs. ${ }^{10}$ Several economic indicators are available to measure a state's fiscal health and thus its ability to meet its competing financial needs. They include the mean income per capita, the state's unemployment rate, and the percentage of persons living in poverty. Unfortunately state fiscal affairs since 2000 have not been improving, many states have been criticized for using tobacco settlement funds for deficit reduction. Population estimates are also included since some economies of scale may be important in the funding of tobacco control programs. In fact, the CDC recommended spending levels are adjusted to reflect state population. ${ }^{11}$

Finally, states with heavy tobacco involvement may have different public sentiment about tobacco control and have different processes governing the allocation of funds to tobacco control programs. In their study on tobacco control funding, Gross and colleagues also tried to identify state characteristics that were associated with their most important predictor, the proportion of settlement revenue that each state allocated to tobacco control. They found that legislatures in tobacco producing states tended to devote a lower proportion of their settlement revenue to tobacco-control programs than did legislatures in other states (12.1 percent vs. 4.1 percent of allocated settlement funds, $\mathrm{P}=0.03) .^{12}$ A study published in 2002 by Morley et al. captured 
industry influence by measuring Tobacco Institute lobbying expenditures across states from 1991-1997 as the outcome. The authors found significant associations between lobby expenditures and a state's cigarette excise tax levels, the status of a state as a recipient of federal ASSIST funds, and changes in the strength of statewide youth access laws. ${ }^{13}$ While the authors did not find a statistically significant association between lobbying expenditures and a state's political affiliation or status as a tobacco producer, they did find that tobacco industry spending was consistently lower in states heavily involved in tobacco growing. While states that produce tobacco will likely have weaker industry lobbying efforts, it is unclear whether tobacco farmers would actively lobby against spending on tobacco control in these states.

\section{Methods}

This study uses data from a variety of national surveillance, economic, and sociodemographic datasets. These data have been compiled to examine state specific factors influencing the funding of state-level tobacco-control programs. Variables measuring public opinion, state political composition, state-level smoking rates, settlement and excise tax revenue, and other control variables are summarized in Table 1. We describe our key variables in more detail below.

\section{Construction of Variables}

\section{$\underline{\text { Outcome: Tobacco Control Funding Per Capita }}$}

Estimates of the outcome variable, each state's total per capita funding of tobacco control programs in fiscal year 2001, were reported as compiled by the $\mathrm{CDC}^{14}$ with the exception of the settlement revenue allocated to tobacco-use prevention, which was reported by the National Conference of State Legislatures (NCSL). ${ }^{15}$ That is, the settlement revenue allocated to tobaccouse prevention reported by NCSL was added to the other state sources including excise tax as well as federal (CDC and the Substance Abuse and Mental Health Services Administration) and 
non-governmental (including the American Legacy Foundation and the Robert Wood Johnson Foundation/American Medical Association Smokeless States National Program) sources to produce each state's total investment in tobacco control for fiscal year 2001. This amount was then divided by the 2001 state population estimates from the Census Bureau to produce per capita funding. These results were then log transformed to produce a more normally distributed outcome enabling the use of parametric statistical techniques.

Appendix Figure 1 reports the range of values by state. Per capita funding in 2001 ranged from pennies in states like Pennsylvania to over \$15 dollars in Maine.

\section{$\underline{\text { Public Opinion }}$}

The 1998-1999 Current Population Survey Tobacco Use Supplement (CPS-TUS) is the principal source for measuring public opinion since it uses a consistent methodology for collecting data across all of the states and provides a sample size sufficiently large enough to produce state-level estimates. ${ }^{16}$ Several opinion questions were asked of all self-respondents who were 15 years or older at the time of interview. To create the index of public opinion, we compiled information from six questions concerning restrictions on smoking in indoor environments. The questions read:

"In \{insert appropriate location $\}$, do you think that smoking should be allowed in all areas, in some areas, or not allowed at all?"

Locations included: restaurants, hospitals, indoor work areas, bars and cocktail lounges, indoor sporting events, and indoor shopping malls. Allowed in all areas was coded as " 0 ", allowed in some areas was coded as "1", and not allowed at all was coded as "2". For each individual the responses were added across all questions yielding scores that ranged from 0 to 12 , with higher numbers representing more restrictive opinions. To normalize the index these scores were divided by 12 and then collapsed across states to produce one summary measure for each state 
ranging from 0 to 1 , with 0 representing the least and 1 the most restrictive opinions. Appendix Figure 2 displays the index by state. The index ranged from .68 in Kentucky to .85 in California, with higher scores representing a greater willingness to restrict smoking in indoor areas. $\underline{\text { Political factors }}$

Information on the partisan composition of each state's legislature was compiled by the Census Bureau from unpublished data obtained from the NCSL. Using these data a dichotomous measure (overall party control) was created to reflect the partisan balance of power (that is, Republican or Democrat) between the governor's office and each bicameral legislative house for each state for 2001 (Nebraska is the only state that has a unicameral legislature). Predominantly Republican states were labeled " 0 " and predominantly Democratic states were labeled " 1 ”. In addition, three separate dummy variables representing the composition of the lower house, the upper house and the party affiliation of the governor were included in some analyses to study independent political effects. Finally, a state ideology score developed by Wright, Erickson, and McIver ${ }^{17}$ was used to measure the ideology of the general population of each state on a liberalmoderate-conservative scale. To produce a measure with good validity and reliability the researchers aggregated CBS News and New York Times polls at the state level on an estimated 76,000 respondents. ${ }^{18}$ The measure ranges from .025 in Vermont to .398 in Idaho, with lower numbers representing a more liberal philosophy and higher numbers a more conservative philosophy of state residents.

\section{Master Settlement Agreement}

Information on state-level revenue from the tobacco settlement agreements (2001) was obtained from data compiled by NCSL from the National Association of Attorneys General. ${ }^{19}$ The total annual payments in 2001 totaled 5 billion. 


\section{$\underline{\text { Smoking Rate }}$}

The percentage of current smokers by state was estimated from the 1998-99 CPS-TUS, ${ }^{20}$ a different source than Gross and colleagues.

Control Variables

Excise Tax Revenue (2000) received by each state was obtained by the CDC from Orechowski and Walker. ${ }^{21}$ Per capita personal income data for 2001 were reported by the Bureau of Economic Analysis (BEA). State population data, the 1999 persons living below the poverty line, and the 2000 State unemployment rate were obtained from the Census Bureau. ${ }^{22}$ Finally, tobacco involvement was reported by the United States Department of Agriculture's Economic Research Service. ${ }^{23}$ The six states with cash receipts from tobacco totaling more than $\$ 100$ million in 2001, North Carolina, Kentucky, Tennessee, South Carolina, Virginia, and Georgia, were defined as tobacco-producing states. These states account for about 94 percent of U.S. tobacco output. $^{24}$ Statistical Analysis

We conduct bivariate analyses and multiple linear regression analyses to investigate the relationship between tobacco control spending and our variables of interest. For bivariate analysis, Pearson correlation coefficients are used for continuous measures and t-tests are used for dichotomous measures. The results of bivariate analyses are used to formulate the regressions. Candidate predictor variables include any of the measures shown to be significant at the .10 level in the bivariate analyses in addition to any variables which confound the relationship between public opinion and the dependent variable.

Results

Table 2 reports the results of the bivariate analysis for the continuously measured variables. Per capita funding was most strongly correlated with the public opinion index and the 
amount of excise tax revenue a state collected, both showing a positive correlation. The proportion of variance in log of tobacco funding that can be explained by variation in the indoor air index is $20.6 \%$. Excise tax revenue explains $14.1 \%$ of the variation in tobacco funding. Other predictors showed moderately significant associations. Settlement Revenue received per capita showed a positive correlation while individuals living in poverty and the percent of current smokers were negatively associated with the amount of funding for tobacco control.

Table 2 also shows the association between total funding per capita and dichotomously measured indicators. States with democratic governors spend more on tobacco control compared to those with republican governors and states that produce tobacco spend less on tobacco control than states with less economic reliance on tobacco growing. No significant associations were seen between 2001 per capita spending and a state's per capita income, population size, unemployment rate, or political ideology. As well, neither the partisan composition of the state's legislature nor an overall measure of party control in the state was significantly associated with 2001 per capita spending on tobacco control.

Table 3 contains results of the regression analyses. Model I contains the public opinion index as the sole explanatory variable. As expected, the public opinion index was positive and significant $(\mathrm{p}<.001)$. Thus, states with stronger public support for indoor air restrictions were more likely to spend a greater amount on tobacco control. Figure 1 illustrates this relationship. The equation for the fitted regression line indicates that for every 1 percentage point increase in the public opinion index, per capita tobacco funding increases by about 16.8 percent. To better illustrate the magnitude of this effect, a standard deviation increase in the public opinion index corresponds to a $55.6 \%$ increase in per capita tobacco funding.

Model II includes all four effects that were hypothesized to be important. Interestingly, the addition of the governor's party affiliation, the smoking rate, and the amount of the state's 
settlement revenue to the model had little effect on the coefficient on the public opinion index. Model II indicates that the governor's party affiliation is important: states with democratic governors spent an average of 64 percent more on tobacco control than states with nondemocratic governors $(\mathrm{p}<.045)$. When controlling for public opinion, the governor's party affiliation, and settlement revenue received, we find the current rate of smoking had no significant effect on tobacco control spending. Finally, while only moderately significant, increases in the amount of the state's settlement revenue did positively impact tobacco control funding levels $(\mathrm{p}<.188)$. A one-dollar per capita increase in the settlement revenue, led to a 2 percent increase in per capita tobacco control spending. In Model III we include the 3 additional variables found to be significant in the bivariate analyses: excise tax revenue, the state poverty rate, and whether the state was a tobacco producing state. Additionally, population was included as a potential confounding variable, since there are economies of scale in state-level program funding and the population variable is moderately significant in the bivariate analysis. These control variables had little effect on the coefficients of the four variables of interest. While the effect of public opinion declined, it is still positive and relatively large in magnitude. Although the public opinion variable is no longer significant, it is not surprising that there is low power given the 8 explanatory variables and only 50 observations. Considering Model III, the adjusted

$\mathrm{R}^{2}$ is .29 , suggesting these 8 variables explain 29 percent of the variation in tobacco control funding.

\section{Discussion}

\section{Public Opinion}

Consistent with our hypothesis, the more willing citizens were to limit smoking in indoor areas the more money was allocated to tobacco control programs in that state. This suggests that public opinion or possibly cultural norms play a role in the political process that eventually leads 
to allocation of the state's budget. The overwhelming amount of money made available by the Tobacco Settlement caused the 2001 allocation decisions to be played out in the media, exposing much of the voting public to the budget proposals and creating a political environment where public opinion was voiced. As reported by NCSL, during the past three legislative sessions, the states have established public commissions and task forces to recommend how the settlement funds should be spent. Additionally, in many states the appropriation committees in the legislatures received written and oral testimony from a wide range of organizations and citizens regarding the use of the tobacco settlement revenue. ${ }^{25}$ Furthermore, several states held ballot initiatives to allow the voting public an active voice in the allocation of settlement funds and/or the allocation of additional revenues arising from increases in the cigarette excise tax. This research suggests that either through elected officials or ballot initiatives state monies were allocated in 2001 by the will of the majority if not the needs.

Moreover, the public opinion index was somewhat robust to other economic and political factors since the coefficient of the public opinion variable remained fairly stable in the multivariate modeling. Based on the significant results from Model II for public opinion and the party affiliation of the governor, an additional model was run considering an interaction between the two variables. The interaction was not significant, indicating that public opinion, as a predictor of tobacco-control funding, is not differentially affected by the party affiliation of the governor.

\section{Political Factors}

The party affiliation of the governor was the most statistically significant political factor considered in our study. Our results suggest that states with democratic governors spend more on tobacco control than their republican counterparts. While gubernatorial budget authority and responsibility as well as veto powers vary from state to state, for the great majority of states, the 
legal authority for formulation of the proposed budget rests with the governor. The significance of this factor is therefore understandable if the party affiliation of the governor affects this initial formulation. However, neither the partisan affiliation of the legislature nor an overall measure of partisan control in the state was a significant factor. Therefore, there is mixed evidence that tobacco control funding is a partisan issue. The political ideology of a state also did not predict the allocation of state monies to tobacco control. While the final budget is a result of political interaction among the state agencies, elected officials, special interest groups and the media and reflects the priorities that emerge after consideration of all the interested parties, this study does suggest that the governor's party affiliation may be a factor in the final budgetary decisions.

\section{Smoking Rates}

Like the findings from Gross and his colleagues ${ }^{26}$, the smoking rate was negatively associated with per capita spending. That is, the more smokers in the state, the less money was allocated to tobacco control in 2001. This result might support the idea that public opinion has an impact on funding since smokers, in general, would be less likely to want restrictions on their

ability to smoke in public areas. It is unclear whether the smoking rate is actually a measure of need, but interestingly in Model II when the other three policy variables are included, the parameter estimate is positive. Perhaps in this instance, because public opinion is being controlled for, the number of current smokers becomes more a measure of need.

\section{Master Settlement Agreement}

The amount of money each state received in 2001 from the tobacco settlement was also a significant factor in the bivariate analysis. That is, the more money a state received the more money was allocated to tobacco control programs; however, other factors seemed to take more precedent in the multiple regression analysis. 


\section{Control Variables}

One notable finding from the analysis of the control variables was the significance of the excise tax revenue. That is, the more revenue received from cigarette excise taxes, the more money was spent on tobacco control programs. Since these tax rates are also set through the political process, they may also be a measure of anti-tobacco sentiment and a proxy for public opinion in addition to measuring an additional funding stream.

\section{Limitations}

We take advantage of a rich array of state level variables, however, state variables also offer some weaknesses relating to measurement. The reported amount of money that each state allocated to tobacco-control programs is susceptible to error. Consistent methods were used to collect this data at the state level, but inaccuracies likely exist when trying to determine how much of say a school-based health education program is related to tobacco-control or how much a tobacco prevention endowment should be annualized. As well, this is a cross-sectional study looking only at the allocation decisions made in 2001. While some state allocations remained consistent in 2002, several states allocated dramatically different amounts to tobacco control in subsequent years. These differences suggest that a more stable measure of tobacco-control funding may be available in the future by averaging several years of funding.

Second, while public opinion was measured in 1998-99 prior to the allocation of funds in 2001, this study does little to suggest how these public opinions were formed or how cultural norms were shaped. That is, whether tobacco-related policies that exist in a state precede changes in public opinion or whether public opinion in a state varies as a consequence of particular policy changes. This study focuses only on allocation decisions that were made in 2001 as a consequence of the tobacco settlement agreements. Thirdly, this study does little to explain the primary mechanism through which the public opinion actually affected allocation 
decisions. The public may have directly contacted public officials or been represented by interest groups or public commissions. The media may have been a factor through polling results, or the overall norms in a state may have already been shared by public officials. Any or all of these factors may have played a role. Discovering the primary mechanism through which public opinion operates is an area for future research.

Fourth, there may be some important omitted variables. For instance, we were unable to measure the effect of special interest groups like the tobacco industry lobby, and other factors like media coverage. As well, we were unable to find a meaningful measure of fiscal health. Each of these factors may also play a role in state-level allocation decisions. Finally, there is a problem with colinearity among explanatory variables in the multivariate models. This fact makes it difficult to accurately interpret individual effects of each predictor.

\section{Conclusions}

Results of this study suggest that public opinion regarding smoking effects the state-level budget allocation to tobacco control programs including the allocation of the settlement funds. The party affiliation of the governor is also found to play an important role. While it is unclear if public sentiment is the most effective way to allocate state monies, it does seem to be more influential than public health needs as defined by the smoking rate. Effective public education to change public opinion and the cultural norms surrounding smoking may impact on political decisions and in turn increase funding for crucial public health programs. Further research is warranted in several areas including the formulation of public opinion and the interaction of public opinion and the political process. A better understanding of these complex interactions may help policy advocates identify intervention strategies to increase tobacco control funding in the future. 


\section{Table 1: Description and Source of Study Variables}

All variables are measured for each of the 50 states except where noted *

\begin{tabular}{|c|c|c|}
\hline Variable & Description/Source & Mean/Freq \\
\hline \multicolumn{3}{|l|}{ Outcome } \\
\hline Tobacco Control & Per capita amount allocated to tobacco control programs in FY & $\$ 3.39$ \\
\hline Funding & 2001 from all sources (log transformed) /CDC and NCSL & $\begin{array}{l}\log \text { transformed: } \\
.6326\end{array}$ \\
\hline \multicolumn{3}{|l|}{ Public Opinion } \\
\hline Public Opinion & $\begin{array}{l}\text { Public Opinion Index concerning restrictions on smoking in } \\
\text { indoor environments, 1998-1999 (higher scores represent more } \\
\text { restrictive opinions) /Tobacco Use Supplement of CPS }\end{array}$ & .775 \\
\hline \multicolumn{3}{|l|}{ Political Factors } \\
\hline Ideology & $\begin{array}{l}\text { Weighted estimate of state ideology and partisanship (lower } \\
\text { values represent more liberal views and higher values more } \\
\text { conservative) /Wright, Erikson \& McIver }{ }^{27}\end{array}$ & $.15075 * *$ \\
\hline Upper House & $\begin{array}{l}\text { Majority party in state upper legislative houses, 2001/U.S. } \\
\text { Census Bureau }\end{array}$ & $\begin{array}{l}48.98 \% \\
\text { democratic* }\end{array}$ \\
\hline Lower House & $\begin{array}{l}\text { Majority party in state lower legislative houses, 2001/U.S. } \\
\text { Census Bureau }\end{array}$ & $\begin{array}{l}51.02 \% \\
\text { democratic* }\end{array}$ \\
\hline Governor & $\begin{array}{l}\text { Party Affiliation of state governors, } 2001 \text { (independents coded } \\
\text { as republican)/U.S. Census Bureau }\end{array}$ & $42 \%$ democratic \\
\hline Party Control & $\begin{array}{l}\text { Political party in control of state legislature, combined over } \\
\text { governor and state legislative houses, 2001/U.S. Census Bureau }\end{array}$ & $\begin{array}{l}46.94 \% \\
\text { democratic* }\end{array}$ \\
\hline \multicolumn{3}{|l|}{ Smoking Rates } \\
\hline Current Smokers & $\begin{array}{l}\text { Percentage of citizens who are current smokers, 1998- } \\
\text { 1999/Tobacco Use Supplement of CPS }\end{array}$ & $21.43 \%$ \\
\hline \multicolumn{3}{|c|}{ Master Settlement Agreement } \\
\hline Settlement Revenue & $\begin{array}{l}\text { Tobacco settlement revenue received from the tobacco industry } \\
\text { in FY2001 per capita/NCSL }\end{array}$ & $\$ 28.08$ \\
\hline \multicolumn{3}{|l|}{ Control Variables } \\
\hline Excise Tax Revenue & $\begin{array}{l}\text { Tobacco excise tax revenue collected in FY2000 per capita/ } \\
\text { CDC from Orzechowski \& Walker }\end{array}$ & $\$ 28.94$ \\
\hline Income & Mean per capita personal income, FY2001/BEA & $\$ 29,068$ \\
\hline Unemployment & Unemployment rate, 2000/U.S. Census Bureau & $3.90 \%$ \\
\hline Poverty & $\begin{array}{l}\text { Percentage of people of all ages living at or below the poverty } \\
\text { line, } 1999 / \text { U.S. Census Bureau }\end{array}$ & $11.44 \%$ \\
\hline Population & $\begin{array}{l}2001 \text { Population estimates based on } 2000 \text { Census per 100,000/ } \\
\text { U.S. Census Bureau }\end{array}$ & 56.85 \\
\hline Tobacco Involvement & $\begin{array}{l}\text { Tobacco producing states of Georgia, Kentucky, North } \\
\text { Carolina, South Carolina, Tennessee, and Virginia/ USDA }\end{array}$ & $\begin{array}{l}12 \% \text { produce } \\
\text { tobacco }\end{array}$ \\
\hline
\end{tabular}

NASBO, National Association of State Budget Officers ${ }^{29}$; CDC, Centers for Disease Control and Prevention $^{30}$; BEA, Bureau of Economic Analysis. ${ }^{31}$; U.S. Census Bureau ${ }^{32}$; NCSL, National Conference of State Legislatures ${ }^{33}$; USDA, U.S. Department of Agriculture ${ }^{34}$;** based on 48 states does not include Hawaii and Alaska; * based on 49 states does not include Nebraska with a unicameral legislature. 
Table 2: Factors Associated with Log of per Capita

Funding of Tobacco Control Programs: Pearson Correlations and T-tests

\section{Correlation with Log per Capita Funding}

\begin{tabular}{|c|c|c|}
\hline & Pearson's Rho & $P$ value \\
\hline \multicolumn{3}{|l|}{ Public Opinion } \\
\hline $\begin{array}{l}\text { Public Opinion } \\
\text { (least } \rightarrow \text { most restrictive) }\end{array}$ & 0.454 & $<0.001$ \\
\hline \multicolumn{3}{|l|}{ Political Factors } \\
\hline \multirow{2}{*}{$\begin{array}{l}\text { Ideology } \\
\text { (liberal } \rightarrow \text { conservative) }\end{array}$} & -0.153 & 0.300 \\
\hline & T-Test & P value \\
\hline \multicolumn{3}{|l|}{ Upper House } \\
\hline Democrat (1) & $0.862 \pm 0.277$ & 0.170 \\
\hline Republican (0) & $0.375 \pm 0.215$ & \\
\hline \multicolumn{3}{|l|}{ Lower House } \\
\hline Democrat (1) & $0.469 \pm 0.264$ & 0.409 \\
\hline Republican (0) & $0.764 \pm 0.234$ & \\
\hline \multicolumn{3}{|l|}{ Governor } \\
\hline Democrat (1) & $1.070 \pm 0.249$ & 0.031 \\
\hline Republican (0) & $0.316 \pm 0.225$ & \\
\hline \multicolumn{3}{|l|}{ Party Control } \\
\hline Democrat (1) & $0.666 \pm 0.296$ & 0.780 \\
\hline \multirow[t]{2}{*}{ Republican (0) } & $0.566 \pm 0.210$ & \\
\hline & Pearson's Rho & P value \\
\hline \multicolumn{3}{|l|}{ Smoking Rates } \\
\hline Current Smokers & -0.274 & 0.054 \\
\hline \multicolumn{3}{|l|}{ Master Settlement Agreement } \\
\hline Settlement Revenue & 0.268 & 0.060 \\
\hline \multicolumn{3}{|l|}{ Control Variables } \\
\hline Excise Tax Revenue & 0.376 & 0.007 \\
\hline Income & 0.108 & 0.456 \\
\hline Unemployment & -0.086 & 0.552 \\
\hline Poverty & -0.248 & 0.083 \\
\hline \multirow[t]{2}{*}{ Population } & -0.205 & 0.152 \\
\hline & T-Test & P value \\
\hline \multicolumn{3}{|l|}{ Tobacco Involvement } \\
\hline Tobacco producing states (1) & $-0.208 \pm 0.402$ & 0.074 \\
\hline Other states $(0)$ & $0.747 \pm 0.184$ & \\
\hline
\end{tabular}


Table 3: Regression Results_Log of Tobacco Control Program Funding Per Capita as the Outcome: Parameter Estimates and Significance Levels for Three Models

\begin{tabular}{|c|c|c|c|c|}
\hline \multirow[b]{2}{*}{ Policy Variables } & \multirow[t]{2}{*}{ Model I } & Model II & \multicolumn{2}{|c|}{ Model III } \\
\hline & & & & \\
\hline Public Opinion & $16.87 * \quad(\mathrm{p}<.001)$ & $(p=.016)$ & 12.37 & $(p=.201)$ \\
\hline Political Factor: Governor & & $(\mathrm{p}=.045)$ & $0.65 *$ & $(\mathrm{p}=.048)$ \\
\hline Current Smokers & & $(p=.613)$ & -2.85 & $(p=.784)$ \\
\hline Settlement Revenue & & $(\mathrm{p}=.188)$ & 0.018 & $(\mathrm{p}=.188)$ \\
\hline \multicolumn{5}{|l|}{ Control Variables } \\
\hline Excise Tax Revenue & & & 0.004 & $(p=.779)$ \\
\hline Poverty & & & -0.036 & $(\mathrm{p}=.563)$ \\
\hline Population & & & -0.0049 & $(\mathrm{p}=.058)$ \\
\hline Tobacco Involvement & & & -0.256 & $(p=.653)$ \\
\hline $\mathrm{R}^{2}$ & .207 & $.264 \dagger$ & & $91 \dagger$ \\
\hline $\mathrm{N}$ & 50 & 50 & & 0 \\
\hline
\end{tabular}

$*$ Significant at $\mathrm{p} \leq .05$

$\uparrow$ Adjusted $\mathrm{R}^{2}$ 
Figure 1: Relationship between Log of Tobacco Control Program Funding per Capita and Public Opinion

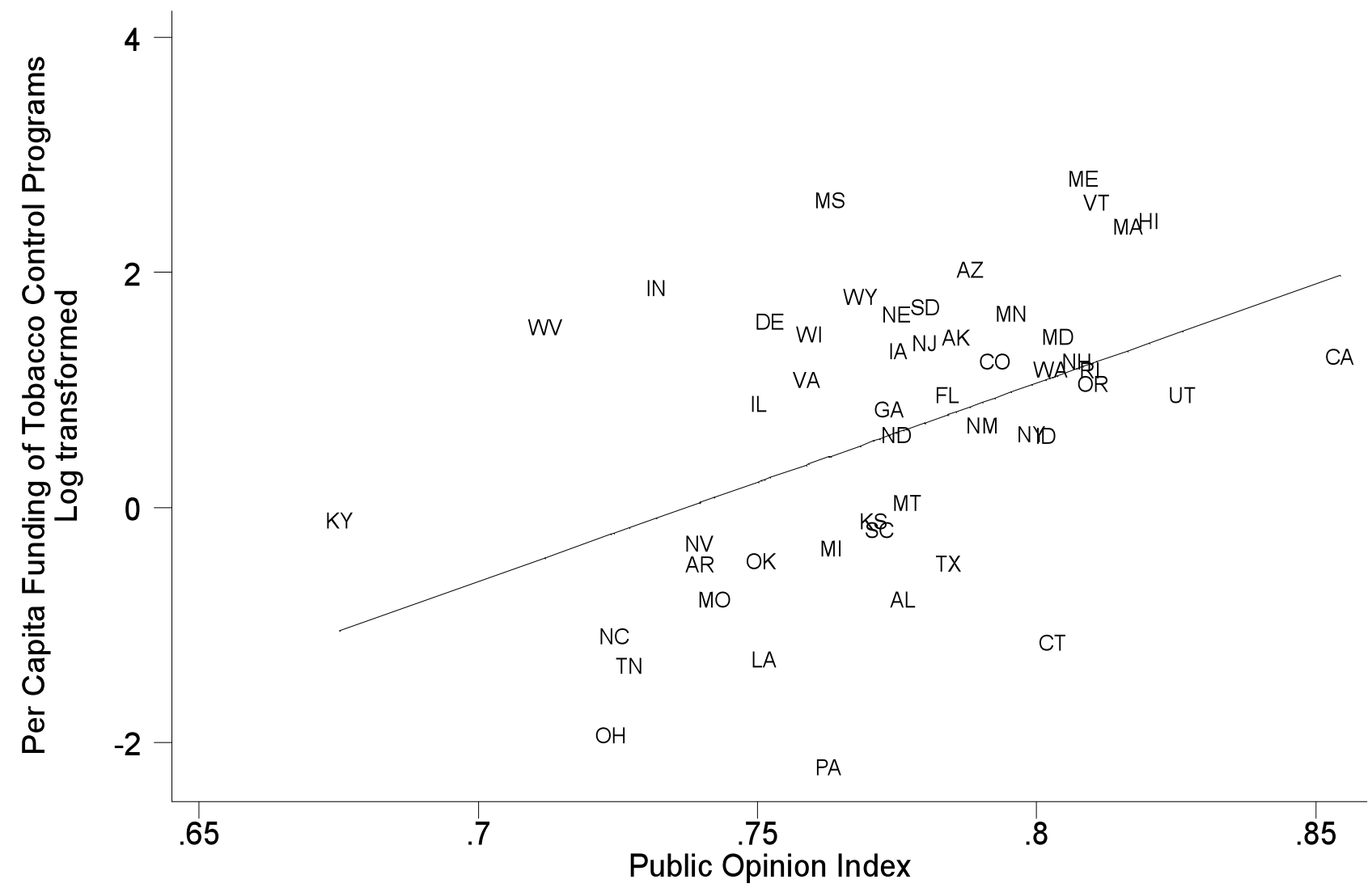




\section{Appendix}

Figure 1: 2001 Per Capita Tobacco Control Spending by State

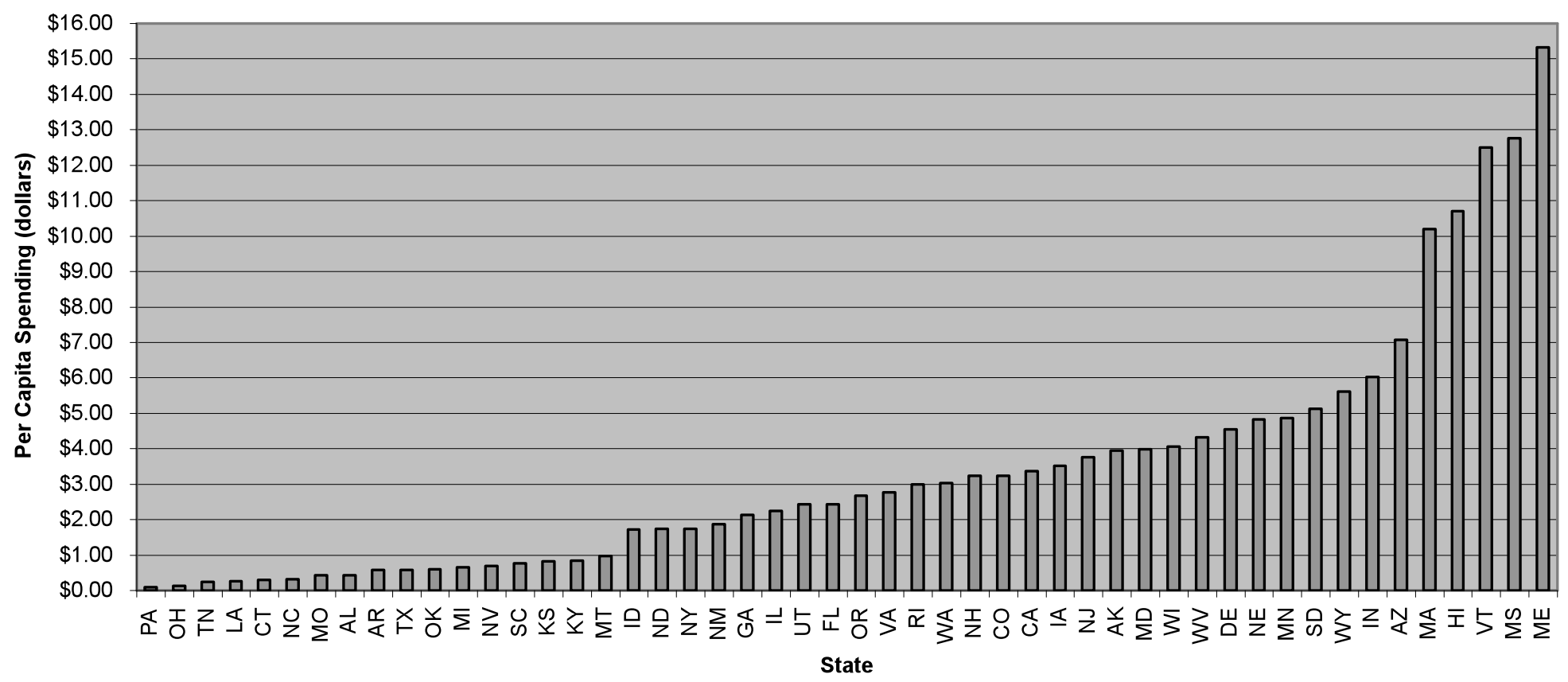


Figure 2: Public Opinion Index by State

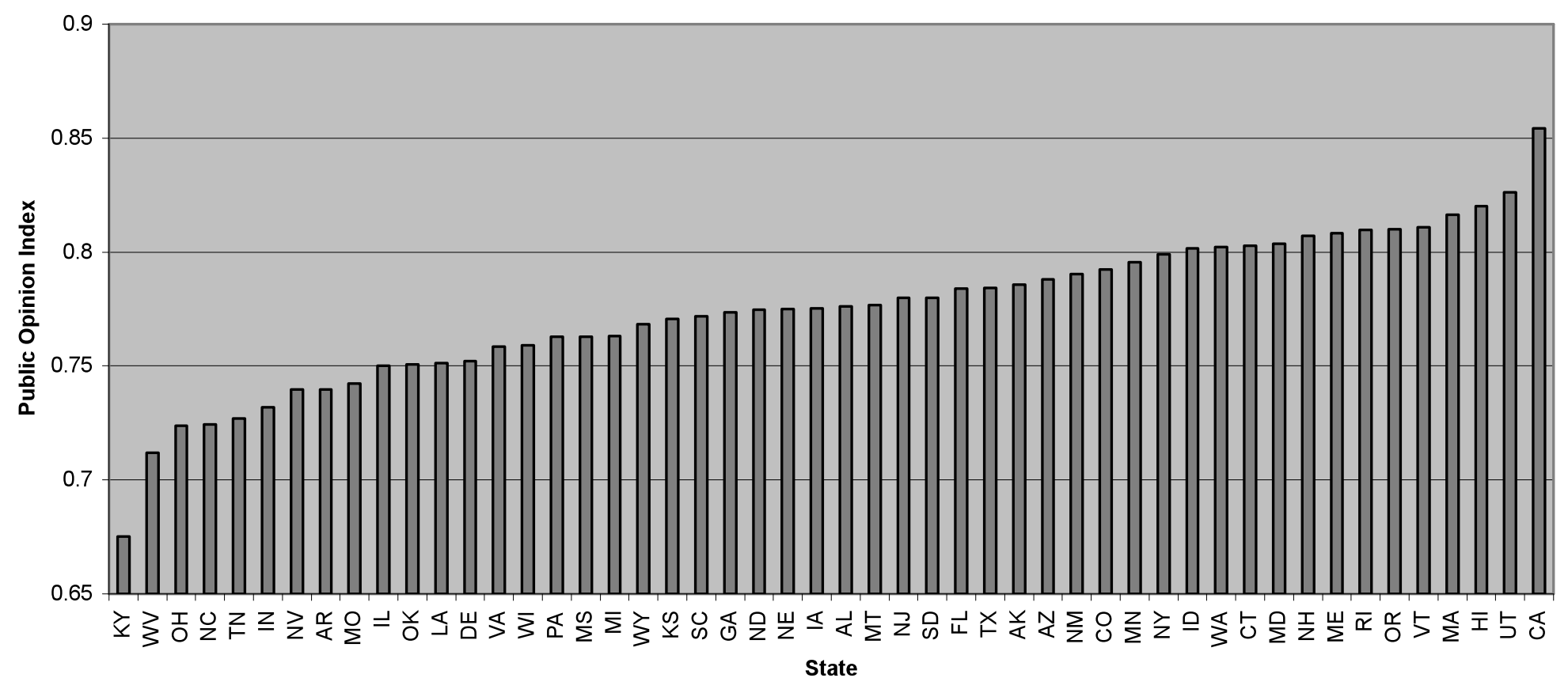




\section{References}

${ }^{1}$ Master Settlement Agreement. Washington, D.C.: National Association of Attorneys General, 2002. (Accessed June 9, 2003, at http://www.naag.org/issues/tobacco/index.php?sdpid=919)

${ }^{2}$ Centers for Disease Control and Prevention. Best Practices for Comprehensive Tobacco Control ProgramsAugust 1999. Atlanta GA: U.S. Department of Health and Human Services, Centers for Disease Control and Prevention, National Center for Chronic Disease Prevention and Health Promotion, Office on Smoking and Health, August 1999.

${ }^{3}$ Master Settlement Agreement. Washington, D.C.: National Association of Attorneys General, 2002. (Accessed June 9, 2003, at http://www.naag.org/issues/tobacco/index.php?sdpid=919)

${ }^{4}$ Gross CP, Soffer B, Bach PB, et al. State Expenditures for Tobacco-Control Programs and the Tobacco

Settlement. The New England Journal of Medicine 2002;347: 1080-1086.

${ }^{5}$ CDC. State-Specific Prevalence of Current Cigarette Smoking Among Adults, and Policies and Attitudes About Secondhand Smoke--United States, 2000. MMWR 2001; 50(49): 1101-1106.

${ }^{6}$ CDC. State-Specific Prevalence of Current Cigarette Smoking Among Adults, and Policies and Attitudes About Secondhand Smoke--United States, 2000. MMWR 2001; 50(49): 1101-1106.

${ }^{7}$ Givel, MS. and SA. Glantz. Failure to Defend a Successful State Tobacco Control Program: Policy Lessons From Florida. American Journal of Public Health 2000; 90(5):762-767.

${ }^{8}$ Luke D.A., Stamatakis K.A., Brownson R.C. State Youth-Access Tobacco Control Policies and Youth Smoking Behavior in the United States. American Journal of Preventive Medicine 2000; 19(3): 180-187.

${ }^{9}$ Wright GC, Erikson RS, McIver, JP. Measuring State Partisanship and Ideology with Survey Data. The Journal of Politics, 1985; 47(2): 469-489.

${ }^{10}$ Pierce-Lavin, Candice and Alan Geller. Creating Statewide Tobacco Control Programs after Passage of a Tobacco Tax. Cancer 1998; 83: 2659-65.

${ }^{11}$ Centers for Disease Control and Prevention. Best Practices for Comprehensive Tobacco Control ProgramsAugust 1999. Atlanta GA: U.S. Department of Health and Human Services, Centers for Disease Control and Prevention, National Center for Chronic Disease Prevention and Health Promotion, Office on Smoking and Health, August 1999.(Accessed June 9, 2003, at http://www.cdc.gov/tobacco/bestprac.htm)

${ }^{12}$ Gross CP, Soffer B, Bach PB, et al. State Expenditures for Tobacco-Control Programs and the Tobacco Settlement. The New England Journal of Medicine 2002;347: 1080-1086.

${ }^{13}$ Morley CP, Cummings KM, Hyland A, Giovino GA, Horan JK. Tobacco Institute lobbying at the state and local levels of government in the 1990s. Tobacco Control, 2002; 11(Suppl 1): 102-109.

${ }^{14}$ Investment in Tobacco Control: State Highlights 2001. Atlanta: Centers for Disease Control and Prevention, 2001: 19.(Accessed June 9, 2003, at http://www.cdc.gov/tobacco/statehi/statehi_2001.htm)

${ }^{15}$ Health Policy Tracking Service. State Management and Allocation of Tobacco Settlement Revenue, 2002. Washington, D.C.: National Conference of State Legislatures.

${ }^{16}$ Hansen, R.H. 1985 July. The Current Population Survey: Design and Methodology. Technical paper No. 40. Washington, DC: Bureau of the Census, U.S. Department of Commerce.

${ }^{17}$ Wright GC, Erikson RS, McIver, JP. Measuring State Partisanship and Ideology with Survey Data. The Journal of Politics, 198; 47(2): 469-489.

${ }^{18}$ Wright GC, Erikson RS, McIver, JP. Measuring State Partisanship and Ideology with Survey Data. The Journal of Politics, 1985; 47(2): 469-489.

${ }^{19}$ Health Policy Tracking Service. State Management and Allocation of Tobacco Settlement Revenue, 2002.

Washington, D.C.: National Conference of State Legislatures.

${ }^{20}$ Hansen, R.H. 1985 July. The Current Population Survey: Design and Methodology. Technical paper No. 40. Washington, DC: Bureau of the Census, U.S. Department of Commerce.

${ }^{21}$ Orzechowski W, Walker RC. The Tax Burden on Tobacco: Historical Compilation 2000. Arlington, VA: Orzechowski and Walker, 2001.

${ }^{22}$ U.S. Census Bureau. Statistical Abstract of the United States: 2001. Washington, D.C.: Government Printing Office, 2001. (Accessed June 9, 2003, at http://www.census.gov/prod/2002pubs/01statab/stat-ab01.html).

${ }^{23}$ U.S. Department of Agriculture. Economic Research Service. "United States and State Farm Income Data"; published 5 August, 2002. (Accessed June 9, 2003, at http://www.ers.usde.gov/data/farmincome/firkdmu.htm.)

${ }^{24}$ Gross CP, Soffer B, Bach PB, et al. State Expenditures for Tobacco-Control Programs and the Tobacco Settlement. The New England Journal of Medicine 2002; 347: 1080-1086.

${ }^{25}$ Health Policy Tracking Service. State Management and Allocation of Tobacco Settlement Revenue, 2002. Washington, D.C.: National Conference of State Legislatures. 
${ }^{26}$ Gross CP, Soffer B, Bach PB, et al. State Expenditures for Tobacco-Control Programs and the Tobacco Settlement. The New England Journal of Medicine 2002;347: 1080-1086.

${ }^{27}$ Wright GC, Erikson RS, McIver, JP. Measuring State Partisanship and Ideology with Survey Data. The Journal of Politics, 1985; 47(2): 469-489.

${ }^{28}$ Orzechowski w, Walker RC. The Tax Burden on Tobacco: Historical Compilation 2000. Arlington, VA: Orzechowski and Walker, 2001.

${ }^{29}$ National Association of State Budget Officers. State Expenditure Report 2001, Summer 2000. Total Expenditures by Fund Source: 98. (Accessed June 9, 2003, at http://www.nasbo.org/publications.php)

${ }^{30}$ Investment in Tobacco Control: State Highlights 2001. Atlanta: Centers for Disease Control and Prevention, 2001: 19.(Accessed June 9, 2003, at http://www.cdc.gov/tobacco/statehi/statehi_2001.htm)

${ }^{31}$ Bureau of Economic Analysis. Regional accounts data: annual state personal income: summary tables 19292001. Washington, D.C.: Department of Commerce, April 2002. (Accessed June 9, 2003, at http://www.bea.doc.gov/bea/regional/spi/.)

${ }^{32}$ U.S. Census Bureau. Statistical Abstract of the United States: 2001. Washington, D.C.: Government Printing Office, 2001. (Accessed June 9, 2003, at http://www.census.gov/prod/2002pubs/01 statab/stat-ab01.html).

${ }^{33}$ Health Policy Tracking Service. State Management and Allocation of Tobacco Settlement Revenue, 2002. Washington, D.C.: National Conference of State Legislatures.

${ }^{34}$ U.S. Department of Agriculture. Economic Research Service. "United States and State Farm Income Data"; published 5 August, 2002. (Accessed June 9, 2003, at http://www.ers.usde.gov/data/farmincome/firkdmu.htm.) 